Article

\title{
Regional Geotourist Resources-Assessment and Management (A Case Study in SE Poland)
}

\author{
Wojciech Zgłobicki ${ }^{1} * \mathbb{C}$, Sylwia Kukiełka ${ }^{1}$ and Bogusława Baran-Zgłobicka ${ }^{2}$ \\ 1 Institute of Earth and Environmental Sciences, Maria Curie-Skłodowska University, Kraśnicka Av. 2d, \\ 20-718 Lublin, Poland; lublinms@gmail.com \\ 2 Institute of Social and Economic Geography and Spatial Management, Maria Curie-Skłodowska University, \\ Kraśnicka Av. 2d, 20-718 Lublin, Poland; bbaran@umcs.pl \\ * Correspondence: wojciech.zglobicki@umcs.pl; Tel.: +48-81-537-6884
}

Received: 20 January 2020; Accepted: 17 February 2020; Published: 19 February 2020

\begin{abstract}
The appropriate identification of the geoheritage resources of a specific area is the sine qua non of the development of geotourism. The identification of tourists' perception of abiotic nature sites of high scientific value is also particularly important because it determines the possibility of using the potential of geosites. In the study, a detailed analysis was carried out of the assets of geological, geomorphological and hydrologic sites in the Central Roztocze region (SE Poland) comprising the central part of the proposed Geopark "Stone Forest in Roztocze". Data from the Polish Central Register of Geosites, the results of a geotourist assessment and questionnaire surveys were used in the analysis. These data indicate a high potential for geotourism development and consistency between scientific assessments and ratings from tourists. However, this potential is not used to a sufficient degree, while actions aimed at developing geotourism and establishing the Geopark are not appreciated by local authorities and institutions responsible for tourism development. The idea of geoparks and geotourism development is not supported by the State either, whether institutionally or financially. Based on the studies conducted, we propose practical measures that should be implemented to increase the use of the region's geotourist assets.
\end{abstract}

Keywords: geoheritage; geopark; geosites; regional development

\section{Introduction}

Geotourism is a form of on-site cognitive tourism focused on geological and geomorphological (landscape) assets [1,2]. It promotes visits to geosites and preservation of geodiversity [3]. Geoparks have a special role in the development of geotourism-" geographical areas where geological heritage sites are part of a holistic concept of protection, education, and sustainable development" [4]. The appropriate use of geoheritage resources of a particular area and the development of the geotourist function should be preceded by a diagnosis of the current state in this respect [5-7]. This enables the planning of the kind of measures aimed at transforming geoheritage resources into geotourist attractions. Such studies constitute an indispensable element of establishing geosites and geoparks. An assessment of geotourist assets can be carried out by means of an expert evaluation [8-12] or questionnaire surveys among tourists and residents [13-17]. Both methods of assessing geoheritage resources have their advantages and limitations. Questionnaire surveys seem to be particularly interesting, owing to the possibility of obtaining information directly from persons who are the actual recipients of a specific geotourist offer. Understanding the profiles, motivation and preferences of tourists is indicated as one of the most significant directions of geotourism studies [6].

The problem of Poland's geotourist assets attracts more and more attention in the scientific literature (e.g., References [18-24], and many others). Three national geoparks have been established, 
and designs of new ones are being prepared. The scientific basis for the development of geotourism is getting better and more complete. However, there is a lack of reliable, popular science information on the geotourist resources of the particular regions, lack of promotion, and a shortage of developed tourist products $[11,24,25]$.

The primary objective of the study was to assess the geotourist resources of the Central Roztocze Region located in south-eastern Poland, for which the design of "The Stone Forest in Roztocze" Geopark was prepared [26]. Using two assessment methods made it possible to compare the perspectives of specialists (scientists) and users (tourists) on the assets of geoheritage sites. Analyses of this kind are carried out relatively rarely. Another objective of the study was to determine whether local authorities and institutions responsible for tourism development appreciate the existence of geotourist assets in this area, as well as possibilities of regional development related to the Geopark project. Our comprehensive studies enabled the identification of the strengths and weaknesses of the region, as well as actions that should be taken to make better use of its geotourist potential.

Until now, three areas in Poland received a national geopark certificate: The Polish part of the cross-border Geopark Łuk Mużakowa (Muskau Arch Geopark) (2009), Geopark Góra Św. Anny (St. Anne's Mountain Geopark) (2010) and Geopark Karkonosze (Karkonosze Mountains Geopark) (2010). The certificates were issued by the Minister of the Environment, but after the establishment of the geoparks above, the State lost interest in this initiative. The Muskau Bend Geopark now has the status of a global UNESCO geopark, and the "Geopark Łuku Mużakowa" association works in its territory (http://geopark.muzakowski.pl/). The legal status of geoparks in Poland is undefined: There are no formal grounds for the functioning and management of geoparks. There is no organisation or association dedicated to the development of geotourism on the national scale. Geoparks are isolated projects that currently receive no support from the State. The geopark area partially overlaps with the national park area (Karkonosze Mountains Geopark) or nature reserve area (St. Anne's Mountain Geopark). The protection of geoheritage assets in Poland is based on the protection of areas and objects: National parks, nature reserves, natural phenomena. In the case of a geopark, the location within a protected area with a strict conservation regime may be an obstacle to the geopark's development because the supremacy of protecting outstanding natural assets, including geodiversity precludes the full achievement of the goals for which geoparks are established. Only the cooperation of nature protection services, local authorities and tourist organisations can intensify the development of geotourism.

The study encompassed detailed investigations of the central part of the proposed geopark in Central Roztocze, characterised by a high intensity of tourist traffic and concentration of major geotourist attractions. Tourists are attracted mainly by the region's high diversity of landscapes. The landforms and elements of the geological structure of this meso-region become the destination for more and more tourists who begin to appreciate its geotourist assets. One can also observe an improvement in tourism infrastructure, which increases the accessibility of assets not only along general tourist trails, but also geotourist trails $[27,28]$. There are many indications that geotourism has a high potential for development but, for the time being, this potential is not fully used.

\section{Materials and Methods}

\subsection{Geoheritage Resources of Central Roztocze}

Roztocze is an elongated morphological ridge extending from the NW to the SE, between the Lublin Upland and the Volhynia-Podolia Upland in the north and north-east and the Sandomierz Basin in the south (Figure 1). It is a series of elevations reaching 300-400 m a.s.1., rising 100-150 m above the surrounding areas [26]. The morphological escarpments of Roztocze correspond to the fault lines separating it from the depressed neighbouring areas; hence, it has the character of a horst dissected by several displacements into numerous blocks [29]. The Roztocze ridge is composed of 
Upper Cretaceous opoka (silica-calcareous marine sedimentary rock), gaize (glauconitic sandstone) and marl that form a horizontally distributed, thick lithological complex [30].

Patches of younger Tertiary deposits lying on the Cretaceous rock include sandstone, conglomerates, Serpula and Lithothamnium limestone. Tertiary limestone overlying Upper Cretaceous rock was eroded, due to its low resistance to destructive factors. They survived only on residual hills. The surface deposits of Central Roztocze are primarily Quaternary sandy and silty deposits formed as a result of periglacial processes [29].
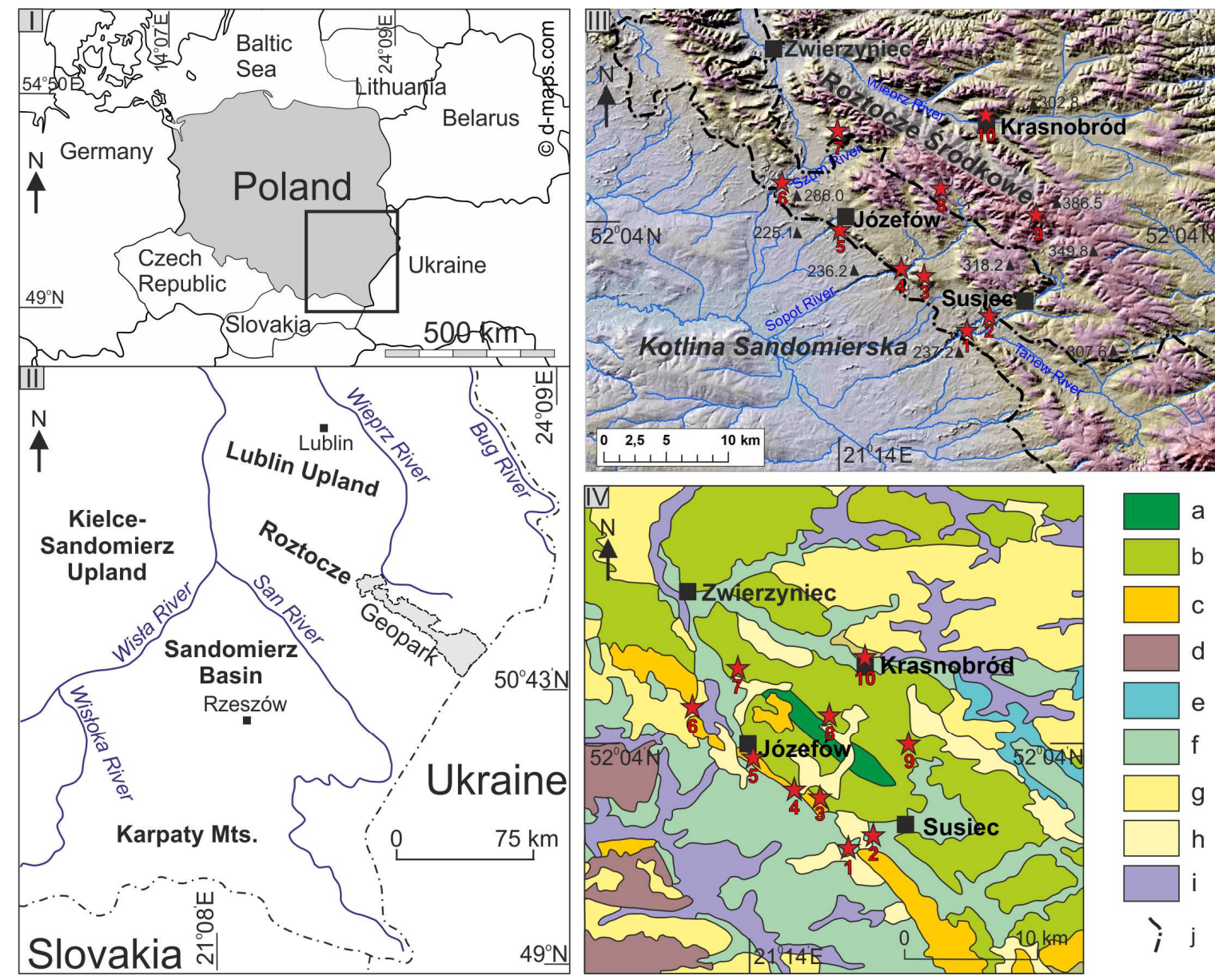

Figure 1. Location of the studied area in Central Europe, rectangle indicates the location of Figure 1.II; (I), SE Poland (II). Location of the studied geosites against: (III) Geomorphology of the Central Roztocze (III), (IV) Geological Map of Central Roztocze (based on [31]). (a) opoka, marl, limestone (Campanian), (b) limestone, chalk, opoka (Maastrichtian), (c) organogenic limestone (Miocene), (d) glacial till, sand and gravel (Pleistocene), (e) lacustrine sand and loam (Pleistocene), (f) fluvial sand, gravel and loam (Pleistocene), (g) loess (Pleistocene), (h) aeolian sand (Pleistocene), (i) fluvial sand, gravel and alluvial deposits (Holocene), (j) border of the proposed Geopark. 1-Nad Tanwia nature reserve, 2-Waterfall on the Jeleń river, 3-Quarry in Nowiny, 4-Sopot river gap valley in the Czartowe Pole nature reserve, 5-Quarry in Józefów, 6-Szum river gap valley, 7- "Piekiełko" rock forms, 8-Underground quarry in Senderki, 9-Wapielnia Hill, 10-Quarry in Krasnobród.

Flat plateaus built of Cretaceous opoka and dissected by vast valleys are the main landform. Limestone residual hills tower above them, Wapielnia being the highest (386.2 $\mathrm{m}$ a.s.1.). In the south, Central Roztocze is delimited by a distinct escarpment zone consisting of several morphological elements parallel to each other. In the west, it is composed of a chain of hills formed by Tertiary rocks. 
The land relief features deep and narrow gap valleys of the Sopot, Tanew and Szum rivers. Series of cascades in Cretaceous or Tertiary rocks are visible in the river channels [32].

The proposed Geopark "Stone Forest in Roztocze" is $65 \mathrm{~km}$ long (NW-SE) and 2-18 km wide, covering an area of about $640 \mathrm{~km}^{2}$. It encompasses a considerable piece of the western part of Eastern Roztocze, the southern piece of Central Roztocze (its escarpment zone), and a small piece of Western Roztocze. The name of the Geopark is related to the pieces of fossil trunks and branches of Taxodioxylon taxodii Gothan occurring in this area [26]. Within the proposed geopark, about 150 geosites that can form the basis of geotourism development were indicated, including 85 located within Central Roztocze (the central part of the Geopark). Most of the geosites in this area are geological outcrops and exposures (40 sites), water sites, i.e., springs, waterfalls and lakes (23), geomorphological sites (16), and sites related to cultural heritage (6). Below is a description of the most important geosites of the proposed Geopark, located within parts of Central Roztocze intensively visited by tourists (Figure 2). Seven of them are located within the Central Roztocze Geotourist Trail [33]. The waterfall on the Jelen river, the Szum river gap valley, and "Piekiełko" rock forms are situated off the trail.

Nad Tanwią nature reserve (1)—Numerous cascades forming small waterfalls are visible in the gap valley of the Tanew river. The biggest waterfalls reach a height of $1.2 \mathrm{~m}$. The formation of the cascades is linked to the vertical uplifting movements of Roztocze occurring since the Neogene until the present [32]. The most noteworthy geotourist assets of the nature reserve include the deeply incised valley of the Tanew river, the cascades revealing the geological structure of the area, the meandering river channel, and numerous outcrops of Upper Cretaceous, Miocene and Holocene rocks [21].

Waterfall on the Jelen river (2) - The highest waterfall in Roztocze $(1.5 \mathrm{~m})$ formed on a cascade in the Jelen river channel built of Cretaceous gaize.

Quarry in Nowiny (3) - Cretaceous gaize covered by Miocene limestone can be observed in this inoperative quarry. The quarry walls reach the height of $12 \mathrm{~m}$. Outcrops of Upper Badenian deposits-calcarenite-occur in the walls. Miocene limestone was quarried here for many years. The site is located in the vicinity of two tourist trails [33].

Sopot river gap valley in the Czartowe Pole nature reserve (4) - A unique geotourist asset in the nature reserve is the deeply incised valley featuring cascades forming riffles between 25 and $90 \mathrm{~cm}$ high (Figure 2a). They formed on layers of Miocene limestone [33]. An educational path was designated along the river.

Quarry in Józefów (5) - It is one of the few where it is possible to admire the sedimentary features of the Miocene deposits. The outcrops show organogenic limestone, mainly from algae, along with silty deposits. The quarry walls are up to $15 \mathrm{~m}$ tall. This is the biggest quarry in Central Roztocze, and the ongoing quarrying activity is very limited (Figure 2b). A 19-metre observation tower was built at the quarry, offering views of the entire site and the surrounding landscape [33].

Szum river gap valley (6)-The river flows across the escarpment zone of Roztocze, along a winding, narrow and deeply incised valley. The steep slopes of the valley formed in Miocene limestone, quartz sand and Cretaceous gaize. Riffles and small cascades formed along a 300-metre stretch of the river, within gaize outcrops. The relatively steep gradient of the channel results in fast flow rates leading to the formation of cascades. Eleven waterfalls, up to $0.5 \mathrm{~m}$ high, can be found here [33].

"Piekiełko" rock forms (7)—The hill is built of organogenic limestone and Badenian sandy limestone. Several dozen rock forms were created by weathering and mass movements. The largest ones are two "towers", 4.5-5 m tall. Alongside large rocks, there are also smaller forms: Rock ledges, pulpits and ridges [34]. A waymarked educational path with interpretation panels about the origins of the rocks leads to the nature reserve.

Underground quarry in Senderki (8)-The underground galleries, 1 to $1.5 \mathrm{~m}$ high were built in order to obtain millstones. At present, six openings lead to the excavation galleries. Miocene rock occurs here in the form of layers of organogenic limestone, sandy limestone, sandstone and sand. Inoperative quarries, depressions and waste heaps can be seen on the surface. Although the 
underground quarry is not accessible to visitors, an educational path enables the observation of the surface traces of quarrying activity [35].

Wapielnia Hill (9) is a residual hill (subjected to denudation), built of rocks that were uplifted by about $70 \mathrm{~m}$ during the Alpine tectonic movements. Outcrops of reef limestone and Lithothamnium -Bryozoa limestone constituting various rock forms occur at the top of the hill. The limestone obtained here was used in industry and local construction work [21].
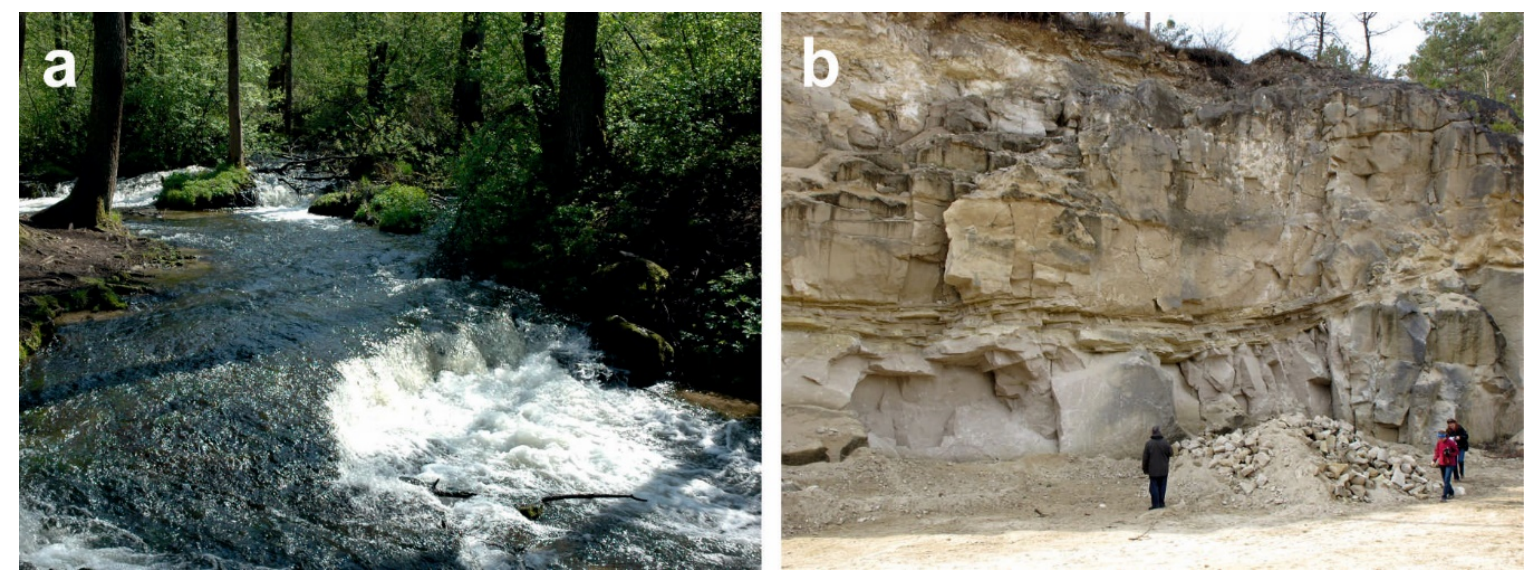

Figure 2. There are two general types of geosites of planned Geopark: River channels with small waterfalls (a) and quarries (b). (a) Sopot river gap valley in Czartowe Pole nature reserve (b) Quarry in Józefów.

Quarry in Krasnobród (10)—Upper Cretaceous opoka was quarried here. The main ingredients of opoka are calcium carbonate and silica formed mainly by various organisms, i.e., Porifera, Bryozoa, Bivalvia, Echinoidea, coccoliths. A small number of fossils can still be seen in the outcrops. The wall of the quarry is about $150 \mathrm{~m}$ long and $25 \mathrm{~m}$ tall. An observation tower stands at the top of the quarry wall [33].

\subsection{Methods}

In the assessment of the geotourist assets of Central Roztocze, a four-stage procedure was adopted. First, the results of the assessment of the scientific, educational and tourist value of the sites located in the region and included in the Polish Central Register of Geosites were analysed (http://geoportal.pgi.gov.pl/portal/page/portal/geostanowiska/). Data concerning the sites located in Central Roztocze were introduced into the register as part of the preparation of the geopark plan. The assessment in the Register is quite subjective because it is not based on specific formal criteria. However, it offers a general image of the value of the sites based on the assessment of experts knowing the region and its geoheritage features. Among the highest rated geosites, ten different sites were selected for further assessment (four river valleys with waterfalls, three quarries, one underground mine and two hills). At the same time, they are sites frequently visited by tourists, widely recognized as the region's largest natural tourist attractions. A detailed assessment of their geotourist assets was then carried out by means of a method developed by the authors (second stage). The attractiveness of the same geosites was also assessed based on the survey of tourists visiting Central Roztocze (four stage). The next step consisted of analyzing strategic documents prepared at various levels of administration-from province to district level-in terms of the presence of information on the possibility of using geoheritage assets for tourism and regional development.

Many methods of assessing the geotourist assets of geoheritage components have been developed so far (see, for example, reviews by Kubaliková [9] and Brilha [12]). The assessment used in the present study includes the criteria used in most evaluations of this kind. It is a modification of the method proposed by Warowna et al. [11]. The assessment comprises 12 criteria belonging to four groups: 
(i) Scientific value, (ii) educational value, (iii) functional value, (iv) tourist value (Table 1). Each criterion was assessed according to a three-degree scale-(i) 0.0, (ii) 0.5 , (iii) 1.0 .

Table 1. Categories and geotourist value assessment criteria.

\begin{tabular}{|c|c|}
\hline Type of the Value & Scores \\
\hline \multicolumn{2}{|r|}{ Scientific } \\
\hline Scientific knowledge & $\begin{array}{l}0.0 \text { - unknown, lack of publications, } 0.5 \text {-less than } 10 \text { scientific publications, } \\
1.0 \text { - more than } 10 \text { publications }\end{array}$ \\
\hline Rarity & $\begin{array}{l}0.0 \text {-not among the top } 3 \text { most important sites, } 0.5 \text { - one of the three most } \\
\text { important sites, } 1.0 \text { - the only occurrence }\end{array}$ \\
\hline Diversity & $\begin{array}{l}0.0 \text { - only one abiotic feature (process), } 0.5-2 \text { visible abiotic features, } \\
1.0 \text { - three and more abiotic features }\end{array}$ \\
\hline \multicolumn{2}{|r|}{ Educational } \\
\hline Representativeness & $\begin{array}{l}0.0 \text {-low representativeness/poor visibility of features, } 0.5 \text { - medium } \\
\text { (primarily for experts), 1.0-high (also for non-experts) }\end{array}$ \\
\hline Exposure (visibility) & $\begin{array}{l}0.0-\text { - obstacles to observation all year round (e.g., vegetation), } 0.5-\text { obstacles } \\
\text { to observation in some seasons of the year, } 1.0-\text { no obstacles to observation }\end{array}$ \\
\hline Educational products & $\begin{array}{l}0.0 \text { - none, } 0.5 \text { - one product related to geoheritage, } 1.0 \text { - two or more } \\
\text { products related to geoheritage }\end{array}$ \\
\hline \multicolumn{2}{|r|}{ Functional } \\
\hline Accessibility (getting there) & $\begin{array}{l}0.0 \text { - by car and more than } 1000 \mathrm{~m} \text { walking distance, } 0.5 \text { - by car and less } \\
\text { than } 1000 \mathrm{~m} \text { walking distance, } 1.0 \text { - by public transport and less than } 500 \mathrm{~m} \\
\text { walking distance }\end{array}$ \\
\hline $\begin{array}{l}\text { Accessibility (difficulty of } \\
\text { reaching the site) }\end{array}$ & $\begin{array}{l}0.0 \text { - difficult access (vegetation, the character of substratum), } 0.5-\text { minor } \\
\text { obstacles to access or accessibility in certain seasons of the year, } 1.0-\text { no } \\
\text { obstacles to access }\end{array}$ \\
\hline $\begin{array}{l}\text { Presence of tourist trails and } \\
\text { educational paths }\end{array}$ & $\begin{array}{l}0.0 \text { - path or trail more than } 3 \mathrm{~km} \text { away, } 0.5 \text { - path or trail up to } 3 \mathrm{~km} \text { away, } \\
1.0 \text { - the site lies on a trail or path }\end{array}$ \\
\hline \multicolumn{2}{|r|}{ Tourist } \\
\hline Biotic or cultural value & $\begin{array}{l}0.0 \text {-no additional value, } 0.5-\text { moderate additional value, } 1.0 \text { — significant } \\
\text { additional value }\end{array}$ \\
\hline Landscape beauty & $\begin{array}{l}0.0 \text { - small aesthetic value, } 0.5 \text { - moderate aesthetic value, } 1.0 \text {-landmark of } \\
\text { the region }\end{array}$ \\
\hline Viewpoints & $\begin{array}{l}0.0 \text {-no viewpoints in the vicinity }(3-4 \mathrm{~km}), 0.5 \text {-viewpoint } 1-2 \mathrm{~km} \text { away } \\
1.0 \text {-viewpoint up to } 1 \mathrm{~km} \text { away (or the site is the viewpoint) }\end{array}$ \\
\hline
\end{tabular}

Besides a general assessment, various ranks were assigned to the individual criteria depending on the degree of the potential tourists' interest in the assets of geoheritage, according to the approach used in such assessments [24,36,37]. Two groups of tourists were distinguished-geotourists for whom the scientific and educational values of geosites are key when assessing sites, and tourists who pay more attention to tourist and functional values. The number of points obtained in the particular groups of criteria was then multiplied by the appropriate coefficients (Table 2).

Table 2. Ranks of criteria groups for different audiences (multiplication coefficient).

\begin{tabular}{ccccc}
\hline & Scientific & Educational & Functional & Tourist \\
\hline Geotourists & 2.0 & 1.5 & 1.0 & 1.0 \\
Tourists & 1.0 & 1.0 & 1.5 & 2.0 \\
\hline
\end{tabular}

A survey questionnaire was the second tool used to obtain information from tourists. The respondents were selected randomly, and the answers were anonymous. The respondents were asked to complete a paper questionnaire with 14 questions concerning the geotourist assets of Central Roztocze (Appendix A). The survey was conducted in the following locations-in Zwierzyniec, Górecko Kościelne, Józefów and Krasnobród-in 2014 and 2015. The respondents came from seven 
provinces: Lubelskie, Mazowieckie, Małopolskie, Śląskie, Podkarpackie, Lubuskie and Świętokrzyskie. A total of 311 survey questionnaires were collected from tourists visiting the areas above.

\section{Results}

\subsection{Geotourist Values}

The synthetic evaluation of 85 geosites in Central Roztocze listed in the Polish Central Register of Geosites indicates that their value is moderate. It should be noted that each value in the Register (scientific, educational and tourist) is assigned a rating from 1 to 10 . Among them, there are sites with a score of 10 points (maximum value) in the individual categories, as well as sites with a score of 3 or 4 points (Figure 3, Table 3). The average scores of the particular groups of values are as follows: (i) Scientific value-4.8; (ii) educational value-4.7; (iii) tourist value-4.9. The correlations (correlation coefficient) between the types of values are the following: Scientific and educational -0.78 ; scientific and tourist -0.31 , educational and tourist -0.6 . Geological sites received higher ratings of their scientific value, while geomorphological and hydrologic sites obtained higher scores for their educational and tourist value.

Table 3. Assessment of the value of 10 selected geosites in Central Roztocze according to data from the Polish Central Register of Geosites (maximum score-30).

\begin{tabular}{ccccc}
\hline Geosite & Scientific & Educational & Tourist & Total Score \\
\hline "Piekiełko" rock forms (7) & 7 & 9 & 9 & 25 \\
Quarry in Nowiny (3) & 8 & 8 & 8 & 24 \\
Szum river gap valley (6) & 8 & 8 & 8 & 24 \\
Nad Tanwią nature reserve (1) & 8 & 8 & 7 & 23 \\
Quarry in Józefów (5) & 8 & 8 & 7 & 23 \\
Underground quarry in Senderki (8) & 5 & 7 & 10 & 22 \\
Sopot river gap valley in Czartowe & 6 & 7 & 8 & 21 \\
Pole nature reserve (4) & 6 & 7 & 7 & 20 \\
Waterfall on the Jeleń river (2) & 3 & 5 & 7 & 15 \\
Quarry in Krasnobród (10) & 4 & 4 & 6 & 14 \\
Wapielnia Hill (9) & &
\end{tabular}

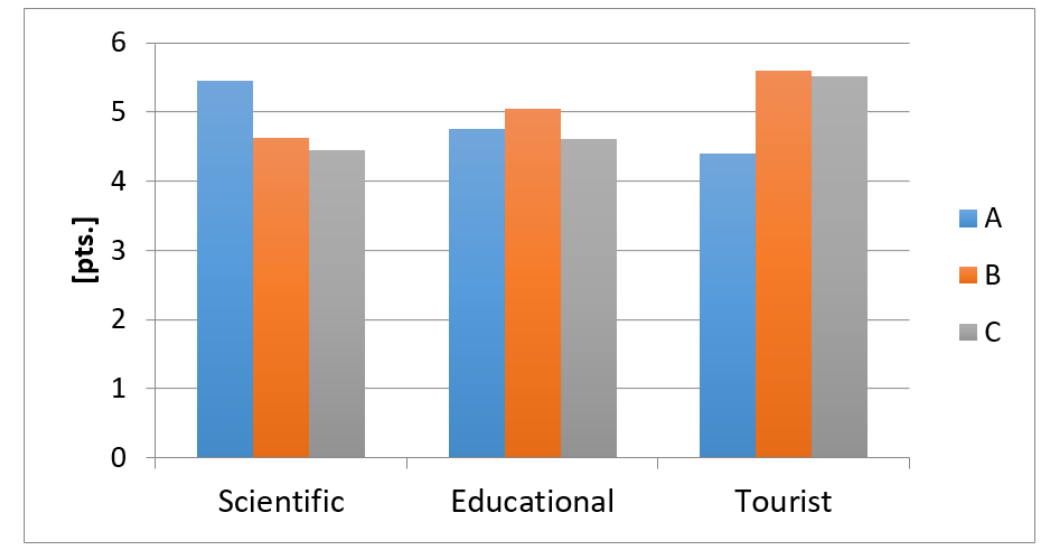

Figure 3. Mean geotourist value rating for geosites in Central Roztocze based on the Polish Central Register of Geosites (rating scale from 1 to 10). A-geological sites (quarries, outcrops), B-geomorphological sites (sand dunes, gullies, hills), C-hydrologic sites (springs, peat bogs, waterfalls). 
On average, the sites received $60 \%$ of the maximum score. It can be, thus, concluded that their geotourist value is moderately high (Table 4). The lowest score was given to the group of tourist values $-30 \%$ of the maximum score. The highest mean scores were obtained by the following criteria: (i) Presence of tourist trails and educational paths, (ii) scientific knowledge, (iii) rarity, (iv) visibility. The lowest mean scores occurred in the case of the following criteria: (i) Presence of viewpoints, (ii) scenic beauty, (iii) additional biotic or cultural assets. Two quarries, in Józefów and Krasnobród, received the highest scores $-87 \%$ and $83 \%$ of the maximum rating, respectively. The lowest rating was obtained by the underground quarry in Senderki and the Wapielnia Hill (33\% and 41\%, respectively).

The synthetic assessment indicates the occurrence of sites with high main values and moderate additional values (Figure 4). With regard to the main values, the highest score was achieved by the Nad Tanwią nature reserve, quarry in Józefów, Sopot river gap valley in the Czartowe Pole nature reserve, and "Piekiełko" rock forms. On the other hand, the quarries in Józefów and Krasnobród, as well as the Sopot river gap valley in the Czartowe Pole nature reserve, were rated as having the highest additional values.

The geoutourist value assessments taking into account various audience groups indicated relatively small differences (Table 5). The differences primarily concern the order of geosites with the highest score even though the top three sites are the same in the case of both assessments. The group of sites with the lowest score also contains the same geosites.

Table 4. Results of the own geotourist assessment of 10 selected geosites in Central Roztocze (maximum score-12).

\begin{tabular}{cccccc}
\hline Geosite & $\begin{array}{c}\text { Total } \\
\text { Score }\end{array}$ & $\begin{array}{c}\text { Scientific } \\
\text { Value }\end{array}$ & $\begin{array}{c}\text { Educational } \\
\text { Value }\end{array}$ & $\begin{array}{c}\text { Functional } \\
\text { Value }\end{array}$ & $\begin{array}{c}\text { Tourist } \\
\text { Value }\end{array}$ \\
\hline Quarry in Józefów (5) & 10.5 & 2.5 & 2.5 & 3.0 & 2.5 \\
Quarry in Krasnobród (10) & 10.0 & 2.0 & 2.5 & 3.0 & 2.5 \\
Nad Tanwią nature reserve (1) & 9.5 & 3.0 & 3.0 & 2.5 & 1.0 \\
Sopot river gap valley in Czartowe & 9.5 & 3.0 & 2.5 & 2.5 & 1.5 \\
Pole nature reserve (4) & 7.5 & 2.5 & 2.5 & 1.5 & 1.0 \\
"Piekiełko" rock forms (7) & 7.5 & 2.0 & 2.0 & 3.0 & 0.5 \\
Quarry in Nowiny (3) & 6.5 & 1.5 & 2.0 & 2.5 & 0.5 \\
Szum river gap valley (6) & 6.5 & 1.5 & 3.0 & 1.5 & 0.5 \\
Waterfall on the Jeleń river (2) & 5.0 & 1.0 & 1.5 & 1.0 & 1.5 \\
Wapielnia Hill (9) & 4.5 & 1.5 & 1.0 & 1.0 & 1.0 \\
Underground quarry in Senderki (8) & 7.3 & 1.9 & 2.0 & 2.0 & 1.0 \\
Mean & & & & &
\end{tabular}

Table 5. The variation of value assessment results among geotourists and tourists.

\begin{tabular}{ccc}
\hline Geosite & Geotourist Score & Tourist Score \\
\hline Nad Tanwią nature reserve & 14.5 & 11.25 \\
Quarry in Józefów & 14.25 & 15.5 \\
Sopot river gap valley in Czartowe Pole nature reserve & 13.75 & 11.25 \\
Quarry in Krasnobród & 13.25 & 14.5 \\
"Piekiełko" rock forms & 11.25 & 9.25 \\
Quarry in Nowiny & 10.0 & 9.5 \\
Waterfall on the Jeleń river & 10.0 & 7.75 \\
Szum river gap valley & 8.0 & 8.25 \\
Wapielnia Hill & 6.25 & 7.0 \\
Underground quarry in Senderki & 6.0 & 5.5 \\
\hline
\end{tabular}




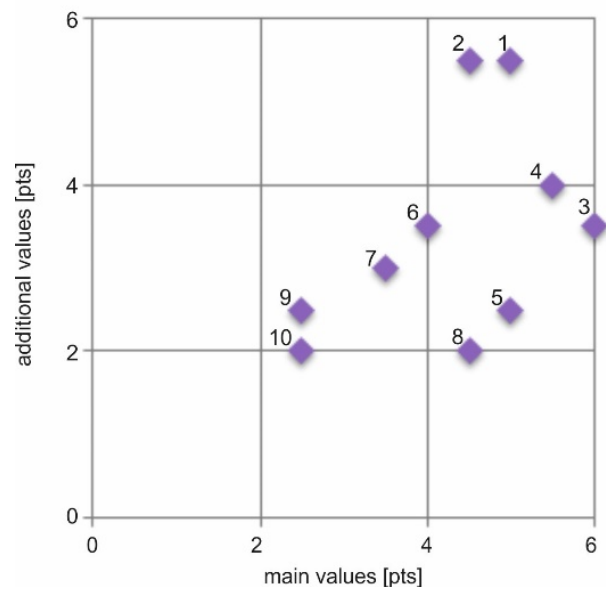

Figure 4. Total main (scientific and educational) and additional values (functional and tourists) for the 10 geosites. 1-Quarry in Józefów, 2-Quarry in Krasnobród, 3-Nad Tanwią nature reserve, 4-Sopot river gap valley in the Czartowe Pole nature reserve, 5- "Piekiełko" rock forms, 6-Quarry in Nowiny, 7-Szum river gap valley, 8-Waterfall on the Jeleń river, 9-Wapielnia Hill, 10-Underground quarry in Senderki.

\subsection{Questionnaire Survey Results}

The possibility of direct contact with nature and of admiring the landscapes and diverse landforms was the main motivation for tourists to come to Central Roztocze (36\%) (Figure 5a). Many respondents were also motivated by the possibility of active leisure (24\%) and visiting interesting historic sites $(20 \%)$. The respondents associated the region primarily with forests and fresh air (36\%) and attractive landscapes (31\%) (Figure $5 b)$.

When rating the tourist attractiveness of a given site, area or phenomenon, $24 \%$ of the respondents take into account mainly aesthetic values, and 22\%-good access to a given tourist attraction (Figure 6). $20 \%$ pay attention to a large number of tourist attractions in the vicinity. $16 \%$ of the respondents regard free admission or low cost of admission as very important.

The respondents looked for information about the geotourist assets of Central Roztocze mostly on the Internet $(43 \%)$, in brochures, flyers, tourist guides $(22 \%)$, and among family and friends $(20 \%)$. Other sources of information were rarely used (Figure 7).
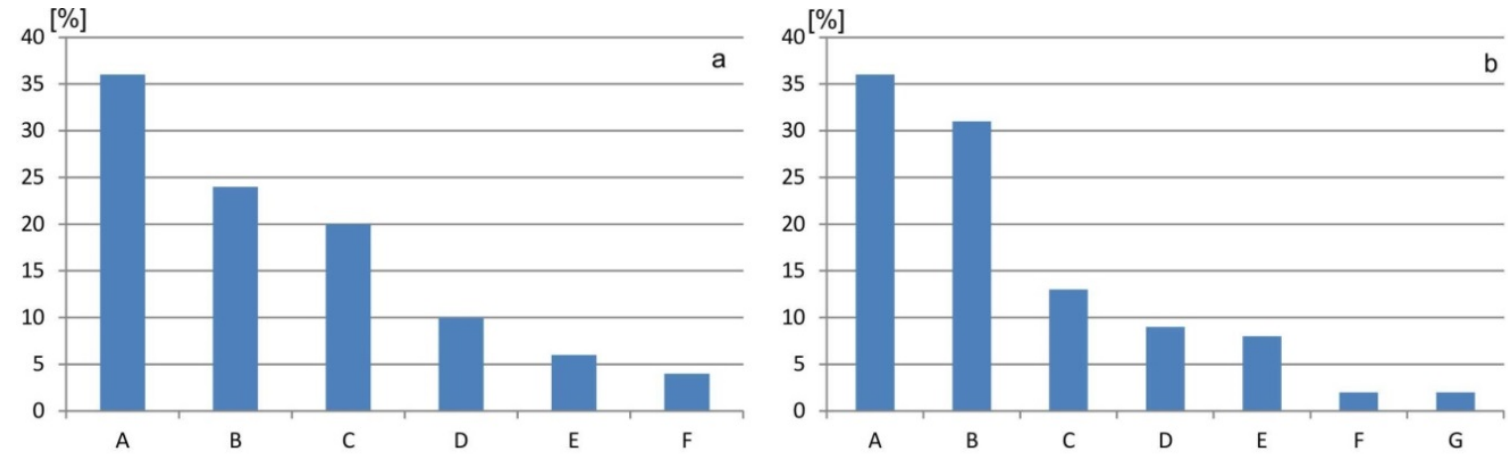

Figure 5. (a) Motivation for coming to Central Roztocze. A-nature tourism, B-active tourism, C-cultural tourism, D-family visit, E-event tourism, F-education. (b) The tourist assets of Central Roztocze. A-forests and fresh air, B-beautiful landscapes, C—active recreation, D—cultural values, E-agritourism, F-regional cuisine, G-tourist infrastructure. 


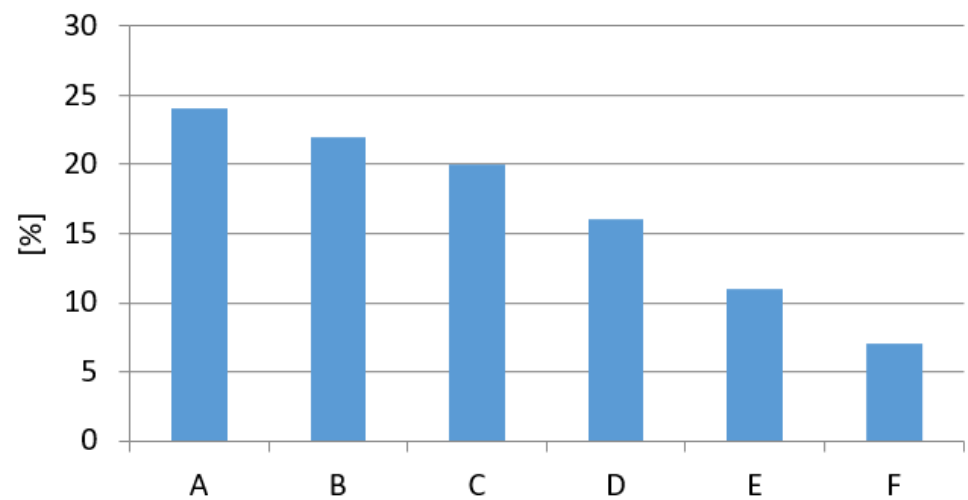

Figure 6. Most significant values for tourists. A-aesthetic value, B — good access, C - many attractions in the vicinity, $\mathrm{D}$-cost of entrance, $\mathrm{E}$-location against tourist trails, $\mathrm{F}$-scientific value.

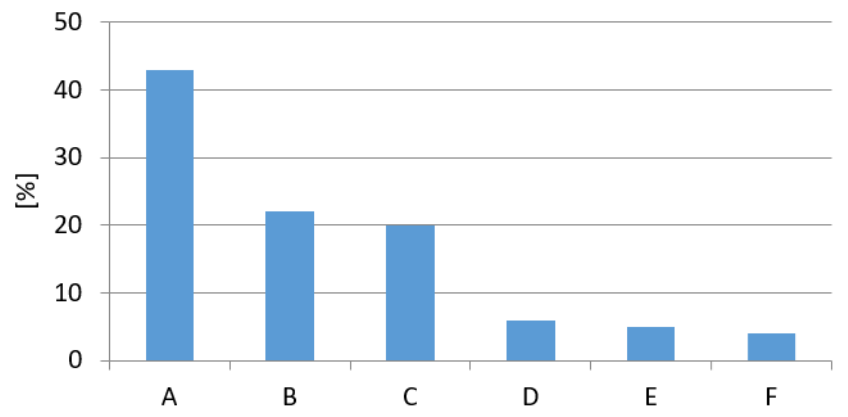

Figure 7. Sources of information about the region and its tourist offer. A-Internet, B-booklets, leaflets, C-friends, family, D-tourist information, E-do not look for information, F-scientific publications.

The term "geotourism" is known to $43 \%$ of the respondents (Figure 8). However, when attempting to define geotourism, $64 \%$ of the tourists gave an incorrect answer. Geotourism was described as tourism focused on natural environment assets, including biotic and abiotic nature. Respondents usually associated geotourism with geography, which was influenced by the prefix geo-. About $36 \%$ of the respondents connected geotourism with geoheritage: "Geological tourism", "tourism related to visiting geological sites" (Table 6). Only $12 \%$ of the tourists were familiar with the term Geopark "Stone Forest in Roztocze". In this case, most of the respondents who declared their familiarity with the term provided a correct answer (Table 7).
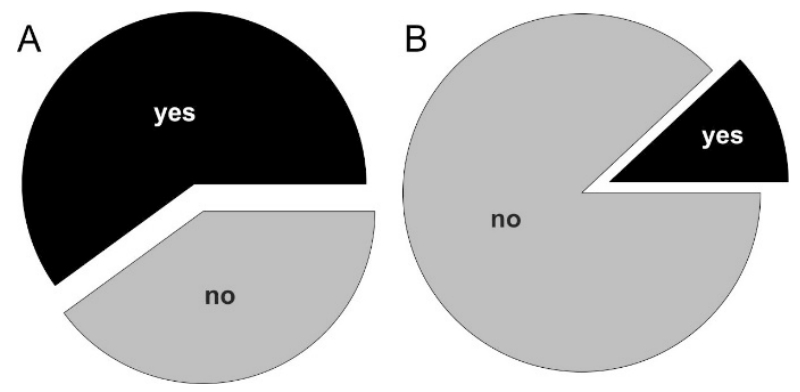

Figure 8. The familiarity of tourists with the term "geotourism" (A), geopark "Stone Forest in Roztocze" (B). 
Table 6. Selected definitions of the term "geotourism" according to respondents.

\begin{tabular}{|c|c|}
\hline & Definitions of Geotourism Provided by Tourists \\
\hline 1. & Tourism related to geology, geological tourism \\
\hline 2. & Tourism related to visiting geological sites \\
\hline 3. & Type of tourism related to the protection of abiotic nature \\
\hline 4. & Visiting forest sites \\
\hline 5. & Discovering the past \\
\hline 6. & Tourism within a specific region \\
\hline 7. & Visiting an area \\
\hline 8. & Discovering a natural phenomenon created without human impact \\
\hline 9. & Discovering the values of a specific natural site \\
\hline 10. & Visiting and discovering geological sites, history of mining, geological history \\
\hline 11. & Discovering the origin of the Earth, its shape, structure, history \\
\hline 13. & Something related to the Earth \\
\hline 14. & $\begin{array}{l}\text { Multifunctional form of tourism-visiting and discovering nature, history of a region, geological } \\
\text { processes }\end{array}$ \\
\hline 15. & Discovering landscape assets \\
\hline 16. & Form of cognitive tourism based on discovering geological sites \\
\hline 17. & Science related to tourism and nature \\
\hline 18. & Term related to the Earth and tourism \\
\hline 19. & Tourism and taking pictures \\
\hline 21. & Tourism related to archaeology, studying the Earth, rocks, caves \\
\hline 23. & Cognitive tourism \\
\hline 24. & Visiting and discovering "green" nature \\
\hline 25. & Tourism and geography \\
\hline 26. & Visiting geographical sites \\
\hline 27. & Tourism related to geographical assets \\
\hline 28. & Tourism related to visiting rocky landforms \\
\hline
\end{tabular}

Table 7. Definitions of the "Stone Forest" Geopark according to the respondents.

Definitions of the "Stone Forest" Geopark Provided by Tourists
Located within the Roztocze region
Stone Forest created as a result of geological processes
An area located within the Roztocze region where one can observe petrified wood
An area with defined borders where sites of high geological value are located
Fossils created as a result of natural processes
Located within the Roztocze region, petrified wood and other fossils
An area important from the geological perspective
An area where one can see petrified wood

A vast majority of the respondents correctly selected four geotourist assets from the prepared set: Fossils (74\% of the respondents), quarries (68\%), springs (64\%), sand dunes (60\%). It should be noted, however, that $46 \%$ of the respondents indicated sites belonging to the category of cultural and biotic assets (Figure 9). The respondents were allowed to choose more than one answer. The respondents mentioned the Kraków-Częstochowa Upland (Jura Krakowsko-Częstochowska) and Central Roztocze as areas of high geotourist value, and the Kaczawskie Mountains and the Suwałki Region as areas of the lowest geotourist value in Poland (Table 8).

The geotourist sites received a relatively high rating from the respondents (Table 9). In the assessment, each site was given a particular rating without any particular criteria (1-lowest rating, 5-highest rating). The five biggest attractions of Central Roztocze include two geotourist sites: Waterfalls on the Tanew river in the Nad Tanwia nature reserve (second place) and the gap valley of the Szum river (fifth place). The synthetic assessment for six geosites was lower than the mean. The lowest scores were received by the underground quarry in Senderki and rock forms in the "Piekiełko" nature reserve. No site received a score lower than 3.5 in a 5-degree scale (1-least attractive, 5-most 
attractive). This means that, in the opinion of visitors, the geotourist assets of Central Roztocze can be regarded as attractive. Religious sites turned out to be the best rated attractions that surpassed $80 \%$ of all geotourist attractions: The church "On the Island" in Zwierzyniec, the church in Krasnobród, and Saint Roch's Chapel.

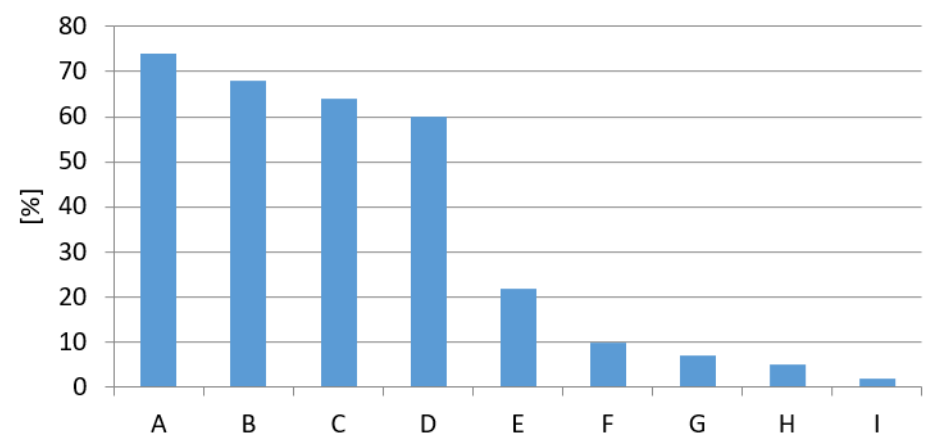

Figure 9. Kinds of geotourist assets (according to tourists). A-fossils, B-quarries, C-springs, D-dunes, E-botanical gardens, F-battlefields, G-manor houses, H-museums, I-festivals.

Table 8. Assessment of the geoutourist value of the selected regions of Poland.

\begin{tabular}{ccc}
\hline Region & Respondents' Assessment & Actual Scientific Value \\
\hline Kraków-Częstochowa Upland & High & High \\
Central Roztocze & High & High \\
Białowieża Forest & Moderate & Low \\
Biebrza Valley & Moderate & Low \\
Nałęczów Plateau & Low & Moderate \\
Kaczawskie Mountains & Low & High \\
Suwałki Region & Low & High \\
\hline
\end{tabular}

Table 9. Respondents' assessment of the value of tourist sites (maximum value-5). Bolded names refer to the geosites studied in the paper.

\begin{tabular}{ccc}
\hline Tourist Site & Mean Score & Lack of Knowledge about the Site (\%) \\
\hline Church “On the Island” in & 4.40 & 17 \\
Zwierzyniec & 4.37 & 16 \\
Nad Tanwią nature reserve & 4.30 & 21 \\
Saint Roch's Chapel & 4.27 & 17 \\
Church in Krasnobród & 4.24 & 39 \\
Sopot river gap valley in the & 4.22 & 33 \\
Czartowe Pole nature reserve & 4.11 & 23 \\
Polish Horse sanctuary & 4.11 & 51 \\
Szum river gap valley & 4.02 & 34 \\
Wapielnia Hill & 4.00 & 51 \\
Quarry in Józefów & 4.00 & 42 \\
Quarry in Nowiny & 4.00 & 41 \\
Quarry in Krasnobród & 4.00 & 31 \\
Waterfall on the Jeleń river & 3.89 & 45 \\
Regional Museum in Krasnobród & 3.69 & 20 \\
“Piekiełko" rock forms & 3.56 & 69 \\
Homestead in Guciów & \\
Underground quarry in Senderki &
\end{tabular}




\section{Discussion}

The questionnaire survey results indicate that a portion of tourists (less than $30 \%$ ) visiting Central Roztocze can be regarded as more or less conscious geotourists. This is confirmed by their correct answers to questions concerning terms, such as geotourism, geotourist attractions, geotourist assessment of regions. At the same time, the assessment of the value of 10 selected geosites, carried out based on the survey results, is consistent with the results of geotourist assessment results-Polish Central Register of Geosites and the assessment developed by the authors. Particularly in the latter case, a large similarity of the assessments occurred, the correlation coefficient is 0.57 (Figure 10). Of course, one can hardly assume that the respondents' assessment was determined by the scientific value of the sites. However, the high synthetic assessment of their tourist value indicates that abiotic nature sites arouse the interest of visitors and can be the basis for the development of geotourism. The favourable perception of geoheritage sites by tourists and residents is of key importance from the perspective of spatial management and preservation of abiotic nature assets [17].

Questionnaire surveys also indicate that there is a group of tourists who do not regard geoheritage assets as important and interesting. Familiarity with the assessed sites plays a very significant role in this respect. A low rating of geosites very often results from the lack of information about them: The correlation coefficient between the assessment results and the respondents' lack of knowledge about geosites is 0.62 . The underground quarry in Senderki is an example of such a site. One can suppose that the situation was similar in the case of the low score of geotourist assets of regions, such as the Kaczawskie Mountains or the Suwałki Region which are actually unique on a national scale in terms of geological structure (remnants of volcanic phenomena and forms) and geomorphology (young glacial landscape). The lack of knowledge about the studied geosites was indicated by 16 to $69 \%$ (average of $38 \%$ ) of the respondents. It should be stressed, however, that the Kaczawskie Mountains and the Suwałki Region are among the most valuable and generally quite frequently visited areas (with few exceptions). In the case of other geosites in Central Roztocze, the level of knowledge about them is clearly lower. Zgłobicki, Baran-Zgłobicka [15] mentioned the significant variation of familiarity with valuable geotourist sites in the area of the potential Małopolska Vistula Gap Geopark.

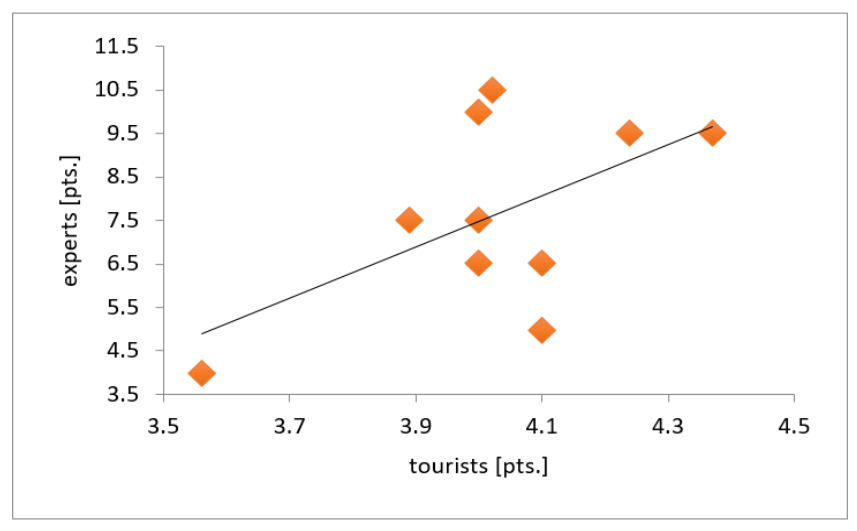

Figure 10. Correlation between tourists' assessment (questionnaire survey) and author's geotourist assessment (data from Tables 4 and 9).

A high degree of consistency between assessments occurs in the case of the following geosites-Nad Tanwia nature reserve, Waterfall on the Jelen river, Sopot river gap valley in the Czartowe Pole nature reserve (Table 10). This applies both to sites of undoubtedly high scientific and tourist value (Nad Tanwia nature reserve, Sopot river gap valley in the Czartowe Pole nature reserve) and those of lower value. A moderate degree of consistency occurs for the Wapielnia Hill and the Quarry in Józefów. In the case of some sites, however, quite a considerable variation of assessments was found, namely-Underground quarry in Senderki, quarry in Nowiny, "Piekiełko" rock forms, Quarry in 
Krasnobród. These differences result primarily from the tourists' poor familiarity with these sites despite their high scientific value.

Table 10. Comparison of the assessment results of selected geosites (their rank).

\begin{tabular}{clll}
\hline Geosites & A & B & C \\
\hline Quarry in Józefów & 3 & 1 & 5 \\
Quarry in Krasnobród & 7 & 2 & 7 \\
Nad Tanwią nature reserve & 3 & 3 & 1 \\
River gap in Czartowe Pole nature reserve & 5 & 3 & 2 \\
"Piekiełko" rock forms & 1 & 4 & 9 \\
Quarry in Nowiny & 2 & 4 & 6 \\
Szum river gap valley & 2 & 5 & 3 \\
Waterfall on the Jeleń river & 6 & 5 & 8 \\
Wapielnia Hill & 8 & 6 & 4 \\
Underground quarry in Senderki & 4 & 7 & 10 \\
\hline
\end{tabular}

A-assessment based on the Polish Central Register of Geosites, B-geotourist assessment developed by the authors, C-tourists' assessment.

The gap valleys of the rivers in Central Roztocze are definitely popular and frequented by tourists. They are among the best rated geomorphological sites in the Lublin Region [15]. They arouse the interest among tourists in other regions of the world as well $[29,38]$.

One of the reasons behind the high rating given by tourists to such geosites is their unquestionable visual (landscape) value. The significance of landscape beauty in the perception, and consequently, assessment of natural components and entire landscapes are indicated by the results of previous studies $[17,39]$. There is no doubt that geotourism can also develop based on the assets of the cultural landscape [40]. In this respect, a special role can be played by a large number of quarries in Central Roztocze $[28,41,42]$. Some of them are located close to important tourist localities, which is a significant advantage. In addition, their tourist and geotourist value are enhanced by the existence of observation towers [43]. The quarries also make it possible to actively learn about geological assets by observing and collecting rocks and fossils. It is particularly important from the perspective of the educational function of geosites, particularly with respect to children and youth [24]. Thus, it seems that the first promotional measures and development of geotourist products in Central Roztocze should be based on greater use of the selected quarries.

Very few people have heard about the proposed geopark, which is not surprising, given that this term is mostly used in the scientific literature. Studies conducted in Kielce (central Poland) at the turn of the 21st century show that even geography students were not familiar with this concept: Only $40 \%$ of them were able to provide a correct definition [14]. At the same time, actions aimed at establishing the geopark seem to be the only possible direction of geotourism development in this area. Therefore, as other authors indicate, it is necessary to conduct in-depth studies on the motivation of tourists visiting abiotic nature sites in Central Roztocze [16].

Tourists indicated certain deficiencies in the geotourism development of Central Roztocze. The most frequently mentioned issues include the lack or inadequate marking of tourist trails, the lack of or insufficiently detailed interpretation panels, poor condition of geotourist sites, lack of information and maps with marked geotourist sites (Table 11). According to tourists, the most important elements are absent, namely the marking of trails and interpretation panels. The only geotourist product developed so far is the Geotourist Trail of Central Roztocze [33], but, since the map of the trail is no longer available for purchase, its impact is limited. Seven among the 10 geosites under study are located on this trail and are "equipped" with geotourist interpretation panels (Figure 11). It seems, however, that these boards need some modification because their current content is sometimes too scientific. 
Table 11. Tourism in the development strategies of districts in Central Roztocze.

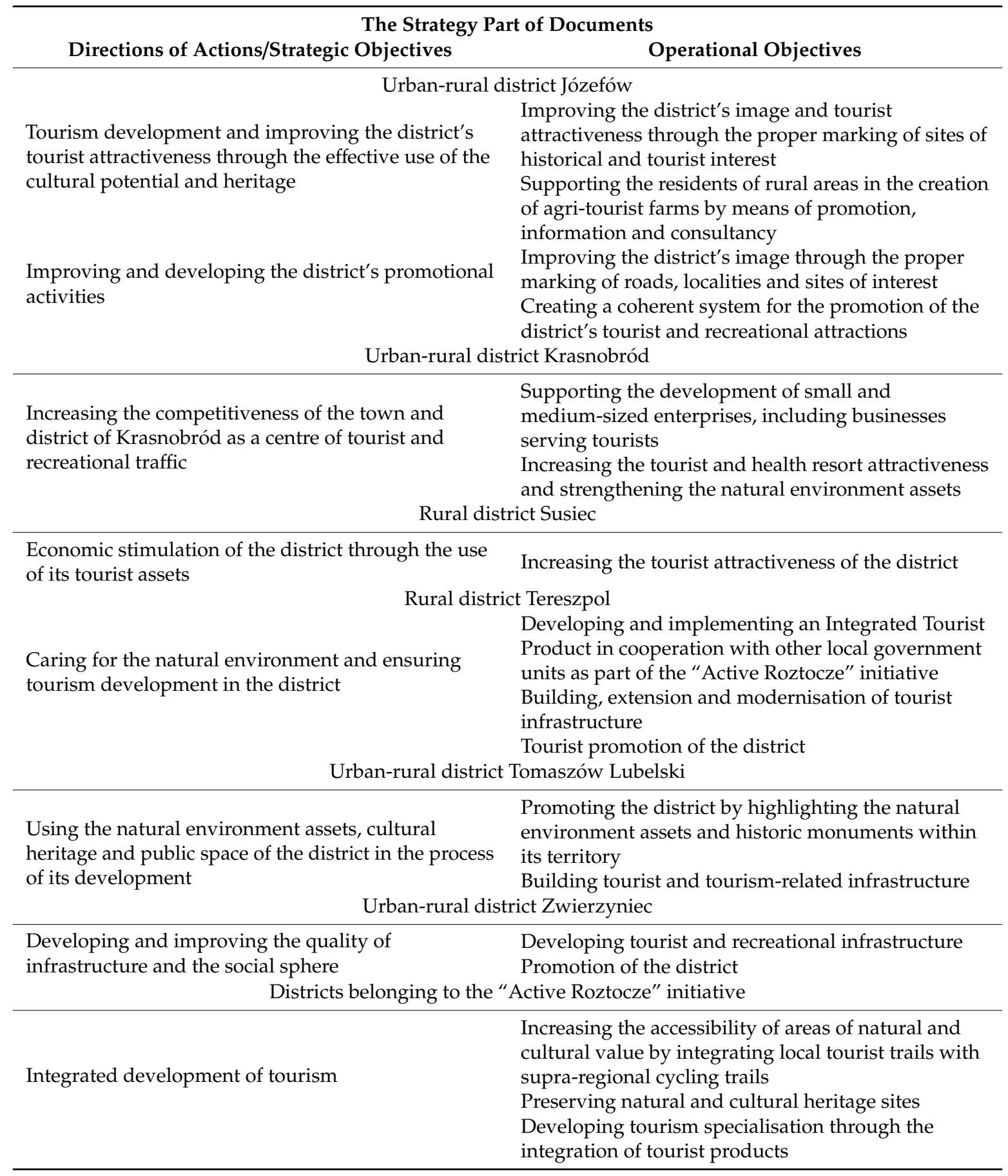



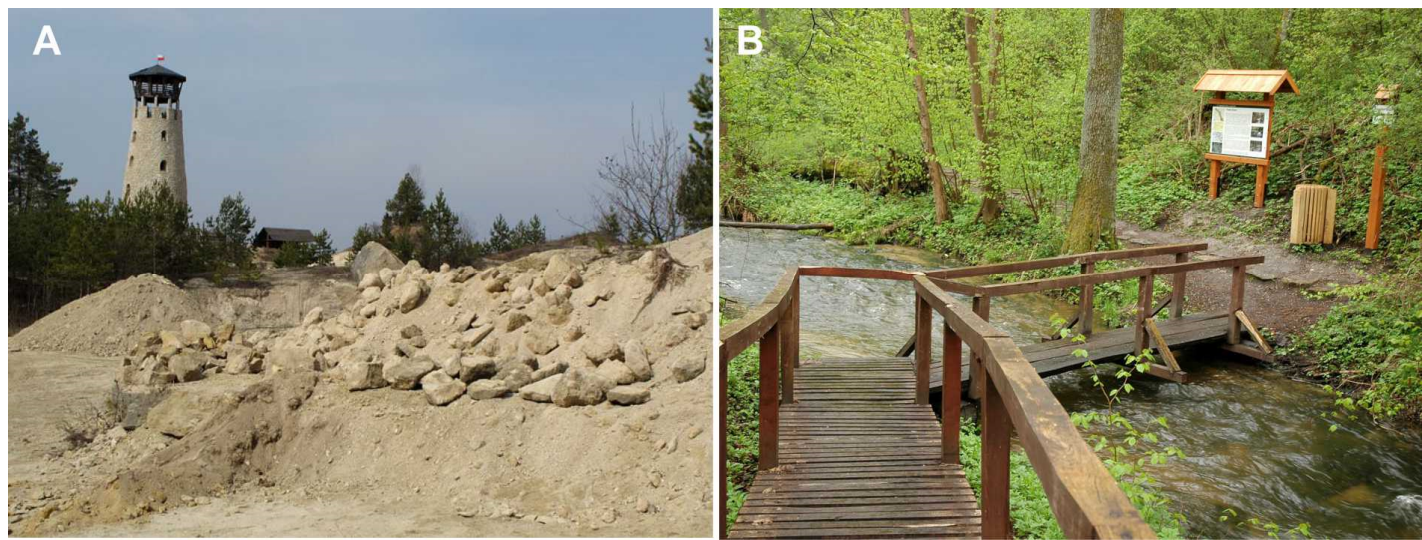

Figure 11. Elements of tourist infrastructure. (A) Observation tower at the quarry in Józefów, (B) Walkways and panels along the educational path in the Czartowe Pole nature reserve.

The peripheral location of the studied area at the Polish-Ukrainian border and in relation to larger cities, is a challenge to the further development of tourism here. There is a lack of good roads to arrive in the area although their condition is improving (Figure 12).

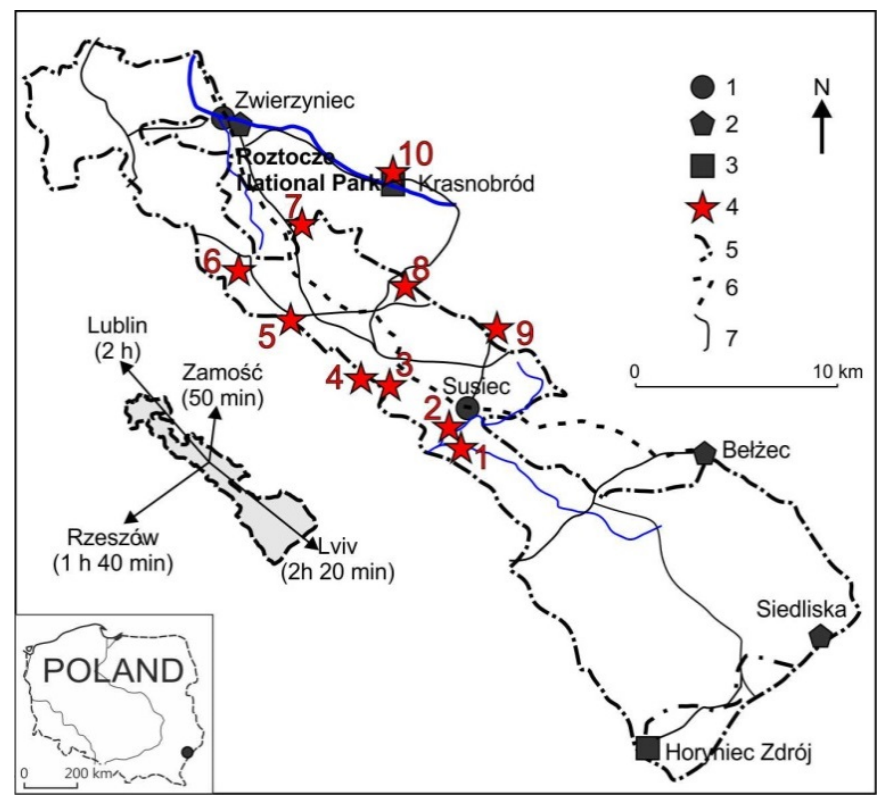

Figure 12. The location of the studied geosites within the proposed geopark and the distance (travel time by car) from larger cities. (1) Main tourist localities, (2) cultural assets-museums, (3) health resorts, (4) geosites, (5) boundaries of the proposed geopark, (6) railway line, (7) main roads. Border of proposed Geopark after Krapiec et al. (2012) [26]

The way of presenting scientific knowledge to tourists is a key challenge to the development of geotourism [44,45]. Studies show that the tourists' knowledge about abiotic nature is distinctly more limited than in the case of the fauna and flora [46]. The same also applies to students of natural science study programmes [14,25]. It is necessary to prepare popular science products presenting geoheritage information in an accessible way. Even in the case of sites of outstanding value, such as the Giant's Causeway, tourists indicate the need for the improvement of interpretation panels with regard to format, size and content [46]. Questionnaire surveys conducted in the vicinity of the Iguazu Falls National Park show that about $70 \%$ of tourists do not read the information presented on the interpretation panels [43]. This may result from the inadequate location of the panels, the poor finishing 
of the panels, or long-winded, hermetic language. On the other hand, individuals who have read the information presented on the panels give them a favourable rating. Well-prepared interpretation panels can, thus, be an important means for tourists to acquire knowledge about the geological and geomorphological assets of a given region.

In modern times, the Internet is the most common and the fastest source of information. The Polish Central Register of Geosites is the database providing information about the geological assets. However, this information is often incomplete, and the descriptions are not easily digestible for ordinary tourists. Efforts should be made to create and launch a geoportal - a database of natural assets (components of biotic and abiotic nature) at the regional level. It could be complemented by a mobile application providing the basic information on the region's natural environment, geosites and geotourist paths. However, Rozenkiewicz et al. [47] indicate that still in Central Europe "information on geotourism resources available online is rather dispersed".

All actions aimed at establishing geoparks and developing geotourism should be based on the involvement of local communities in the process [4]. Therefore, it is necessary to persuade residents that using landscape and preserving geoheritage assets for geotourism purposes generates social and economic benefits [48]. The influence of geoparks on local economy and regional development can occur by means of [49]: (i) Production of geoproducts (souvenirs, handicrafts, geofood), (ii) involving local business in geotourism marketing, (iii) development of recreational and sports activities related to geomorphology and geology (geokayaking, geohiking, climbing). In the case of Central Roztocze, Brzezińska-Wójcik [27] mentions several decorative geoproducts, geofood, and themed towns associated with masonry that can help in the education, interpretation and promotion of geoheritage.

Based on examples from Iceland, Australia and Malaysia, Dowling [48] indicates that the immediate benefits that local communities can derive from the development of sustainable geotourism include increased opportunities for employment and generation of additional revenue. The bottom-up strategy is the most efficient for the promotion and development of geotourism, as well as actions aimed at establishing geoparks. This is exemplified by the activities of the Local Action Group Land of Extinct Volcanoes, encompassing 14 districts in SW Poland, aimed at promoting and educating the public about geoheritage assets [50]. Unfortunately, the attempts to establish such an organisation in Central Roztocze have not been successful so far.

The appropriate positioning of the preservation and tourist use of abiotic nature assets in the spatial planning and economic development system is of fundamental importance to the establishment of the Geopark and the development of geotourism, including its new forms. At the central planning level, in the 2030 National Spatial Development Concept [51], geoparks are merely mentioned in the spatial development vision as elements (nodes) of Poland's ecological network. In the draft National Raw Material Strategy [52], the establishment of geoparks is an action within the preservation of geodiversity.

At the regional level, in the Development Strategy for Lubelskie Province for the years 2014-2020 [53], and in the Spatial Development Plan for Lubelskie Province [54], the Central Roztocze meso-region is in a separate area of strategic intervention-area of the economic use of natural and cultural assets-in "the Roztocze and Solska Forest functional area and areas with identified health resort assets." The Strategy [53] defines the operational objective that encompasses the rational and effective use of natural environment resources for economic and recreational needs, while preserving and conserving the natural environment assets. The Plan [54] also sets out the framework for the conservation of abiotic nature, within which it proposes the establishment of geoparks and placing the most valuable assets of abiotic nature under the protection of the law. It indicates the proposed geopark "Stone Forest in Roztocze" as an area of geological heritage protection that should be used for the extensive promotion of geological sciences and propagation of the educational and tourist functions of geosites, while ensuring their effective protection. According to the Plan, nature and sightseeing tourism using the assets of abiotic nature requires special developmental stimuli. 
The Programme for Tourism Development in Lubelskie Province until 2020 with a perspective until 2030 [55] mentions the problem of geotourism only when indicating the need for tailoring specialised products to specific audiences as part of nature tourism. The lack of a broader approach to geoparks and geotourism in a sectoral problem at the regional level does not create a climate favourable to their development. What is more, the Polish legal system does not provide any regulations concerning the formal establishment, rules of functioning and management of geoparks.

The situation is not much better at the local level. In the development strategies of local governments of six districts within which the sites included in the questionnaire surveys are located, only the abiotic resources and a very general framework of tourism development are presented to a varying extent (Table 11). In some cases, specific measures are indicated, but they do not apply directly to geotourism either. Issues related to tourism are covered most broadly in the Development Strategy of the Town and District of Krasnobród. Districts located in the functional area of Roztocze and Solska Forest [56] established a group called "Active Roztocze", for which a strategic territorial-functional plan was prepared up to the year 2023. The Geopark is indicated as a significant element of the integrated tourist product.

The area of the planned geopark has valuable abiotic nature assets but, at the same time, there are several unfavourable internal factors that pose a serious challenge to the development of geotourism (Table 12). Making the most of the existing potential can be facilitated or impeded by external determinants. Developmental stimuli arising from the formal and legal regulation of the functioning of geoparks, along with the institutional and financial support from central and regional governments, are particularly important.

Table 12. Development of geotourism in Central Roztocze—expert-based SWOT analysis.

\begin{tabular}{|c|c|c|}
\hline & HELPFUL & HARMFUL \\
\hline INTERNAL & $\begin{array}{l}\text { Strengths } \\
\text { - } \quad \text { scientific research results and } \\
\text { documentation of the potential geopark } \\
\text { confirming the valuable geoheritage assets } \\
\text { - } \quad \text { numerous geosites of high geotourist value } \\
\text { - } \quad \text { high level of tourism development } \\
\text { - numerous additional tourist attractions } \\
\text { (including cultural ones) } \\
\text { - existence of the Central Roztocze } \\
\text { Geotourist Trail }\end{array}$ & $\begin{array}{l}\text { Weaknesses } \\
\text { - lack of identification and appreciation of } \\
\text { the geotourist potential in strategy documents } \\
\text { - peripheral location of the area and its poor } \\
\text { accessibility in terms of transport } \\
\text { - lack of qualified tour-guides } \\
\text { - lack of extensive promotion of geotourist } \\
\text { assets } \\
\text { - poor involvement of local communities in } \\
\text { the development of geotourism }\end{array}$ \\
\hline EXTERNAL & $\begin{array}{l}\text { Opportunities } \\
\text { - } \text { establishment of the geopark } \\
\text { - } \text { systemic regulation of the status and } \\
\text { principles of geopark management } \\
\text { - intensive tourist traffic within some } \\
\text { geosites } \\
\text { - development of regional geotourist } \\
\text { products } \\
\text { - growing interest in active and alternative } \\
\text { tourism }\end{array}$ & $\begin{array}{l}\text { Threats } \\
\text { - the lack of support for the idea of } \\
\text { establishing geoparks in Poland } \\
\text { - the lack of understanding of the idea of a } \\
\text { geopark as an opportunity for regional } \\
\text { development } \\
\text { - the lack of financial support for actions } \\
\text { focused on geotourism } \\
\text { - the lack of understanding among local } \\
\text { governments with regard to geotourism } \\
\text { development } \\
\text { - competition from other tourist regions }\end{array}$ \\
\hline
\end{tabular}

Spatial planning does not offer any practical solutions with regard to the tourist use of geoparks because the planning of spatial development is merely a segment of spatial planning. The problems of the location and rules of the functioning of tourist infrastructure are discussed in planning documents on a par with problems related to housing and economy, social and technical infrastructure, environmental protection, etc. These problems as a whole are regulated by the Act on Spatial Planning 
and Development [57]. At the same time, the formal links between strategic and spatial planning are quite loose at the local level. It should be stressed that the geoparks are not discussed in the current Act on Nature Conservation [58]. Since they do not exist in the legal system, including the laws on nature conservation, it is very difficult to take the initiative to establish and manage them. The lack of a formal framework makes it impossible to obtain organizational and financial support for the process of geopark creation. They are not included in the spatial planning system either. Only the proposed National Raw Materials Policy mentions the protection of geodiversity through the establishment of geoparks, among other measures. Geoparks were mentioned only in the bill on the Polish Geological Agency with the attached Council dealing with the certification of geoparks and responsible for information, education and promotion. At the same time, there are no regulations imposing an obligation to prepare master plans for geoparks.

Geotourism, as a form of the sustainable development of rural areas and using land resources of high natural value, requires the involvement of local small business, as well as appropriate instruments and management [48]. Local governments in Poland are not actively initiating the creation of geoparks or supporting the actions of local communities [59]. The lack of systemic regulation of the formal status and management rules of geoparks is currently the biggest challenge. The need to protect geoheritage, on the one hand, and appropriate tourist development, on the other, forces the conflict-free coexistence of various functions in the use of space. The proper functioning of geoparks, stimulating local development, requires appropriate provisions in strategy and planning documents at various levels of government. Particularly significant is the local level where, due to the autonomy of districts with regard to planning, it is necessary to introduce detailed provisions into planning documents. In the context of tourism (including geotourism) planning and management, it is necessary to develop strategies of tourism development. In the case of geoparks, it is indispensable to prepare professional master plans [60] that are the basis for the operation of managing bodies, typically established by way of agreements of local governments, and enable the practical implementation of the idea of a geopark as part of business [61]. A geopark should be managed by a clearly defined structure, operating in accordance with the provisions of the law that would also enable the preservation of the assets and sustainable development. The body managing a geopark could play an active role in the economic development of a region. It should cooperate with local businesses in order to promote and support the creation of new products associated with geological heritage [60-65].

\section{Conclusions}

Central Roztocze is one of the most important potential areas for the development of geotourism in south-eastern Poland. The relatively large tourist traffic offers opportunities for building an offer based on geoheritage assets. The number of geotourist products existing here is distinctly greater than in another potential geopark in the region-the Małopolska Vistula Gap.

Some tourists can be regarded as conscious geotourists, able to accurately identify the assets of abiotic nature and for whom these assets are an important factor in making the decision to visit an area. However, the knowledge of the idea of establishing the Geopark in Central and Eastern Roztocze is very poor, which results from the total lack of promotion of the idea.

The present study found a strong consistency between the respondents' assessments and geotourist assessments. What is particularly important, sites of significant scientific value received high ratings, which creates the possibility of using the educational potential of the geosites.

The fundamental challenge to the development of geotourism and establishment of the Geopark is the total lack of activity among local governments and local communities in this respect. They do not regard the Geopark and geotourism as an opportunity for the economic development of the area. This may result from a lack of familiarity with the idea of geoparks, which shows the need for research on the perception of geotourism among residents.

The main obstacle to the creation of geoparks and their inclusion in the economic development of the region through the development of geotourism is the lack of legal regulations concerning the rules 
of their functioning and management. These sites are not integrated into the system of economic and spatial development planning at a more detailed level. At the same time, the idea of geoparks will not be able to develop without the institutional and organizational support from the State.

Author Contributions: Conceptualization, W.Z. and S.K.; methodology, W.Z. and S.K.; investigation, W.Z., S.K., B.B.-Z.; writing-original draft preparation, W.Z. and B.B.-Z.; writing-review and editing, W.Z. and B.B.-Z.; visualization, W.Z. All authors have read and agreed to the published version of the manuscript.

Funding: This research received no external funding.

Acknowledgments: The authors wish to thank the Editors and anonymous reviewers for their valuable comments and suggestions to improve the quality of this paper.

Conflicts of Interest: The authors declare no conflict of interest.

\section{Appendix A}

Geotourist values of Central Roztocze-questionnaire survey

Faculty of Earth Sciences and Spatial Management, Maria Curie-Sklodowska University

Al. Kraśnicka 2cd 20-718 Lublin

The aim of the study is to gather information on the motivation of visitors to Central Roztocze and to determine geotouristic values of the region. The survey is anonymous, and the information collected will be for scientific purposes only.

\section{Which of the above motives prompted or will lead you to come to Central Roztocze?}

Please select, at most, two answers

Cultural tourism (architectural monuments)

Nature tourism (the possibility of communing with nature, admiring landscapes, topography)

Active tourism (biking, walking, Nordic walking, kayaking)

Family visit

Event tourism (imprezy kulturalne, rozrywkowe)

$\square \quad$ Educational

2. What do you associate with Central Roztocze most?

Please select, at most, two answers

Forests and fresh air

Cultural values

Well-developed tourist infrastructure

Agrotourism

Active tourism

Regional cuisine

Beautiful landscapes

3. What do you pay attention to when assessing the tourist attractiveness of a given object, area or phenomenon?

Please select, at most, three answers

Good access to tourist attraction

Cost of entrance

Aesthetic value

Many atractions in the vicinity

Scientific value

Location against network of tourist trails

4. Where are you looking for or would you like to find information about the geotouristic values of Central Roztocze? 
$\square \quad$ Booklets, leaflets

$\square \quad$ Internet

$\square \quad$ Opinions of friends and family

$\square \quad$ Scientific publications

$\square \quad$ I am not looking for such information

5. Do you know the term "geotourism"?

$\square \quad$ Yes

$\square \quad \mathrm{No}$

6. Please try to explain the concept of geotourism

7. Do you know the concept of the Stone Forest Geopark in Roztocze?

$\square \quad$ Yes

$\square \quad$ No

8. Please try to explain the concept of Stone Forest Geopark in Roztocze

9. Choose geotourist values from the list below

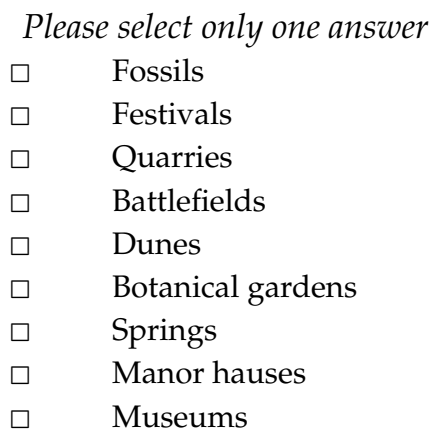

10. Which of the regions of Poland do you consider to be the most geotouristically attractive?

$\begin{array}{ll}\square & \text { Białowieżą Forest } \\ \square & \text { Central Roztocze } \\ \square & \text { Biebrza River Valley } \\ \square & \text { Nałęczów Plateu } \\ \square & \text { Suwałki region } \\ \square & \text { Kaczawskie Mountains } \\ \square & \text { Kraków-Częstochowa Upland }\end{array}$

11. How do you assess the attractiveness of individual tourist attractions in Central Roztocze?

1-no attractive 5-very attractive

Please mark only one answer per line 
1. Church "On the Island" in Zwierzyniec

2. Polish Horse sanctuary

3. Nad Tanwia nature reserve

4. Saint Roch's Chapel

5. Church in Krasnobród

6. Szum river gap valley

7. Underground quarry in Senderki

8. "Piekiełko" rock forms

9. Waterfall on the Jeleń river

10. Quarry in Józefów

11. Regional Museum in Krasnobród

12. Quarry in Krasnobród

13. Wapielnia Hill

14. Homestead in Guciów

15. Sopot river gap valley in the Czartowe Pole nature reserve

16. Quarry in Nowiny

$\begin{array}{lllllc}1 & 2 & 3 & 4 & 5 & \text { I don't know } \\ \square & \square & \square & \square & \square & \square \\ \square & \square & \square & \square & \square & \square \\ \square & \square & \square & \square & \square & \square \\ \square & \square & \square & \square & \square & \square \\ \square & \square & \square & \square & \square & \square \\ \square & \square & \square & \square & \square & \square \\ \square & \square & \square & \square & \square & \square \\ \square & \square & \square & \square & \square & \square \\ \square & \square & \square & \square & \square & \square \\ \square & \square & \square & \square & \square & \square \\ \square & \square & \square & \square & \square & \square \\ \square & \square & \square & \square & \square & \square \\ \square & \square & \square & \square & \square & \square \\ \square & \square & \square & \square & \square & \square \\ \square & \square & \square & \square & \square & \square \\ \square & \square & \square & \square & \square & \square\end{array}$

12. Please indicate deficiencies in the geotourism development of Central Roztocze

13. Age

$\begin{array}{ll}\square & 18-25 \text { years } \\ \square & 26-35 \text { years } \\ \square & 36-45 \text { years } \\ \square & 46-60 \text { years } \\ \square & \text { more 60 years }\end{array}$

14. Education

$\begin{array}{cl}\square & \text { Primary } \\ \square & \text { Secondary } \\ \square & \text { Higher }\end{array}$

15. Place of stay (province)

Thank you for completing the survey! $\odot$

\section{References}

1. Dowling, R.K. Geotourism's global growth. Geoheritage 2011, 3, 1-13. [CrossRef]

2. Hose, T.A. 3 G's for modern geotourism. Geoheritage 2012, 4, 7-24. [CrossRef]

3. Newsome, D.; Dowling, R.K. Setting an agenda for geotourism. In Geotourism: The Tourism of Geology and Landscape; Newsome, D., Dowling, R., Eds.; Goodfellow Publishers Limited: Oxford, UK, 2010; pp. 1-12.

4. Global Geoparks Network. Guidelines and Criteria for National Geoparks Seeking UNESCO's Assistance to Join the Global Geoparks Network (GGN). Available online: http://www.unesco.org/new/fileadmin/ MULTIMEDIA/HQ/SC/pdf/sc_geoparcs_2010guidelines.pdf (accessed on 31 December 2019).

5. Ólafsdóttir, R.; Tverijonaite, E. Geotourism: A Systematic Literature Review. Geosciences 2018, 8, 234. [CrossRef]

6. Kubalíková, L. Assessing Geotourism Resources on a Local Level: A Case Study from Southern Moravia (Czech Republic). Resources 2019, 8, 150. [CrossRef] 
7. Selmi, L.; Coratza, P.; Gauci, R.; Soldati, M. Geoheritage as a Tool for Environmental Management: A Case Study in Northern Malta (Central Mediterranean Sea). Resources 2019, 8, 168. [CrossRef]

8. Pralong, J.P. A method for assessing tourist potential and use of geomorphological sites. Geomorphol. Relief Process. Environ. 2005, 11, 189-196. [CrossRef]

9. Kubaliková, L. Geomorphosite assesment for geotourism purposes. Czech J. Tour. 2013, 2, 80-104. [CrossRef]

10. Kubalíková, L.; Kirchner, K. Geosite and geomorphosite assessment as a tool for geoconservation and geotourism purposes: A case study from Vizovicka vrchovina highland (eastern part of the Czech Republic). Geoheritage 2016, 8, 5-14. [CrossRef]

11. Warowna, J.; Zgłobicki, W.; Kołodyńska-Gawrysiak, R.; Gajek, G.; Gawrysiak, L.; Telecka, M. Geotourist values of loess geoheritage within the planned Geopark Małopolska Vistula River Gap, E Poland. Quat. Int. 2016, 399, 46-57. [CrossRef]

12. Brilha, J. Inventory and quantitative assessment of geosites and geodiversity sites: A review. Geoheritage 2016, 8, 119-134. [CrossRef]

13. Kim, S.S.; Kim, M.; Park, J.; Guo, Y. Cave tourism: Tourists' characteristics, motivations to visit, and the segmentation of their behavior. Asia Pac. J. Tour. Res. 2008, 13, 299-318. [CrossRef]

14. Wójtowicz, B. The attitude and expectation of the local community toward development of geological tourism in protected areas near the city of Kielce and the Świętokrzyski region. Probl. Ekol. Kraj. 2011, 29, 123-132. (In Polish)

15. Zgłobicki, W.; Baran-Zgłobicka, B. Geomorphological Heritage as a Tourist Attraction. A Case Study in Lubelskie Province, SE Poland. Geoheritage 2013, 5, 137-149. [CrossRef]

16. Fung, C.K.; Jim, C. Segmentation by motivation of Hong Kong Global Geopark visitors in relation to sustainable nature-based tourism. Int. J. Sustain. Dev. World Ecol. 2015, 22, 76-88. [CrossRef]

17. Martins, B.; Pereira, A. Residents' Perception and Assessment of Geomorphosites of the Alvão-Chaves Region. Geosciences 2018, 8, 381. [CrossRef]

18. Alexandrowicz, Z. Geoparki-nowe wyzwanie dla ochrony dziedzictwa geologicznego. Przeglad Geol. 2006, $54,36-41$.

19. Solarska, A.; Hose, T.A.; Djordjije, A.; Vasiljević, D.A.; Mroczek, P.; Jary, Z.; Marković, S.B.; Widawski, K. Geodiversity of the loess regions in Poland: Inventory, geoconservation issues, and geotourism potential. Quat. Int. 2013, 296, 68-81. [CrossRef]

20. Koźma, J. Transgraniczny Geopark Łuk Mużakowa. Przegląd Geol. 2011, 59, 276-290.

21. Słomka, T. (Ed.) Katalog Obiektów Geoturystycznych w Obrębie Pomników i Rezerwatów Przyrody Nieożywionej; AGH: Kraków, Poland, 2012.

22. Migoń, P.; Pijet-Migoń, E. Overlooked geomorphological component of volcanic geoheritage: Diversity and perspectives for tourism industry, Pogórze Kaczawskie Region, SW Poland. Geoheritage 2015, 8, 333-350. [CrossRef]

23. Alexandrowicz, Z.; Alexandrowicz, W.P.; Buczek, K. Conservation of the Natura 2000 Areas in the Context of Environmental Changes in Past and Present: A Case from the Polish Carpathians Geoheritage. Geoheritage 2019, 11, 517. [CrossRef]

24. Gajek, G.; Zgłobicki, W.; Kołodyńska-Gawrysiak, R. Geoeducational Value of Quarries Located Within the Małopolska Vistula River Gap (E Poland). Geoheritage 2019, 11, 1335-1351. [CrossRef]

25. Zgłobicki, W.; Kołodyńska-Gawrysiak, R.; Gawrysiak, L. 2015: Gully erosion as a natural hazard: The educational role of geotourism. Nat. Hazards 2015, 79 (Suppl. 1), 159-181. [CrossRef]

26. Krapiec, M.; Jankowski, L.; Margielewski, W.; Urban, J.; Krapiec, P. Geopark "Kamienny Las na Roztoczu" i jego walory geoturystyczne. Przeglad Geol. 2012, 60, 468-479.

27. Brzezińska-Wójcik, T. Strategia hands-on activity w kreowaniu geoproduktów w kontekście edukacji, interpretacji i promocji geodziedzictwa na Roztoczu (Środkowowschodnia Polska). Ekon. Probl. Tur. 2015, 1, 169-193.

28. Brzezińska-Wójcik, T.; Skowronek, E.; Świeca, A. Nature and culture heritage in the tourist offer of the border region of Roztocze. Sci. Rev. Phys. Cult. 2017, 7, 129-142.

29. Buraczyński, J. Roztocze, Budowa-Rzeźba-Krajobraz; Wydawnictwo UMCS: Lublin, Poland, 1997.

30. Leszczyński, K. Rozwój litofacjalny późnej kredy Niżu Polskiego. Biul. Państw. Inst. Geol. 2010, 443, 33-54.

31. Marks, L.; Ber, A.; Gogołek, W.; Piotrowska, K. (Eds.) Geological Map of Poland 1:500 000; Polish Geological Institute-National Research Institute: Warsaw, Poland, 2006. 
32. Brzezińska-Wójcik, T. Aktywność tektoniczna w strefie krawędziowej Roztocza Tomaszowskiego w świetle wskaźników morfometrycznych. Ann. UMCS B 1997, 52, 57-75.

33. Brzezińska-Wójcik, T.; Grabowski, T.; Moskal, A.; Pawłowski, A.; Wiechowska, I. Część Opisowa do Mapy “Szlak Geoturystyczny Roztocza Środkowego", Informator-Mapa Turystyczna 1:50,000; Kartpol: Lublin, Poland, 2011.

34. Złonkiewicz, Z. Zabytki skałkowe Roztocza. Ochr. Przyr. 1990, 47, 309-333.

35. Gazda, L.; Ruska, A. Górnictwo kamieni młyńskich w Senderkach. In Historia i Współczesność Górnictwa na Terenie Lubelszczyzny; Krzowski, Z., Ed.; Wydawnictwo Politechniki Lub.: Lublin, Poland, 2005; pp. 54-62.

36. Božić, S.; Tomić, N. Canyons and gorges as potential geotourism destinations in Serbia: Comparative analysis from two perspectives-general geotourists' and pure geotourists'. Open Geosci. 2015, 7, 531-546. [CrossRef]

37. Różycka, M.; Migoń, P. Customer-Oriented Evaluation of Geoheritage-on the Example of Volcanic Geosites in the West Sudetes, SW Poland. Geoheritage 2018, 10, 23-37. [CrossRef]

38. Cocean, G.; Cocean, P. An assessment of gorges for purposes of identifying geomorphosites of geotourism value in the Apuseni Mountains (Romania). Geoheritage 2017, 9, 71-81. [CrossRef]

39. Zgłobicki, W.; Baran-Zgłobicka, B.; Ziółek, M.; Ziółek, G. Atrakcyjność wizualna krajobrazu polskich parków narodowych a ich wartości przyrodnicze. Parki Nar. Rezerw. Przyr. 2005, 24, 135-151.

40. Gordon, J.E. Geoheritage, Geotourism and the Cultural Landscape: Enhancing the Visitor Experience and Promoting Geoconservation. Geosciences 2018, 8, 136. [CrossRef]

41. Brzezińska-Wojcik, T. 2017, Zasoby przyrody nieożywionej Roztocza jako podstawa kreowania obszarowego produktu turystycznego. Zeszyty Nauk. Wyższej Szkoły Tur. Języków Obcych Warszawie 2017, 2, 5-22.

42. Brzezińska-Wójcik, T.; Skowronek, E. Tangible Heritage of the Historical Stonework Centre in Brusno Stare in the Roztocze Area (SE Poland) as an Opportunity for the Development of Geotourism. Geoheritage 2020, 12, 10. [CrossRef]

43. Migoń, P.; Pijet-Migoń, E. Viewpoint geosites-Values, conservation and management issues. Proc. Geol. Assoc. 2017, 128, 511-522. [CrossRef]

44. Moreira, J.C. Interpretative panels about the geological heritage-A case study at the Iguassu Falls National Park (Brazil). Geoheritage 2012, 4, 127-137. [CrossRef]

45. Migoń, P.; Pijet-Migoń, E. Interpreting Geoheritage at New Zealand's Geothermal Tourist Sites-Systematic Explanation Versus Storytelling. Geoheritage 2017, 9, 83-95. [CrossRef]

46. Crawford, K.R.; Black, R. Visitor understanding of the geodiversity and the geoconservation value of the Giant's Causeway world heritage site, Northern Ireland. Geoheritage 2012, 4, 115-126. [CrossRef]

47. Rozenkiewicz, A.; Widawski, K.; Jary, Z. Geotourism and the 21st Century-NTOs' Website Information Availability on Geotourism Resources in Selected Central European Countries: International Perspective. Resources 2020, 9, 4. [CrossRef]

48. Dowling, R.K. Global geotourism-An emerging form of sustainable tourism. Czech J. Tour. 2013, 2, 59-79. [CrossRef]

49. Farsani, N.; Coelho, C.; Costa, C. Geotourism and geoparks as novel strategies for socio-economic development in rural areas. Int. J. Tour. Res. 2011, 13, 68-81. [CrossRef]

50. Pijet-Migoń, E.; Migoń, P. Promoting and Interpreting Geoheritage at the Local Level—Bottom-up Approach in the Land of Extinct Volcanoes, Sudetes, SW Poland. Geoheritage 2019, 11, 1227-1236. [CrossRef]

51. Koncepcja Przestrzennego Zagospodarowania Kraju 2030, Monitor Polski; Uchwała Rady Ministrów nr 239; Warszawa, Polska, 2012; p. 252. Available online: http://prawo.sejm.gov.pl/isap.nsf/DocDetails.xsp?id= WMP20120000252 (accessed on 18 February 2020).

52. Ministerstwo Środowiska. Projekt Polityki Surowcowej Państwa; Ministerstwo Środowiska: Warszawa, Poland, 2018.

53. Urząd Marszałkowski Województwa Lubelskieg. Strategia Rozwoju Województwa Lubelskiego na Lata 2014-2020 (z Perspektywa do 2030 Roku); Urząd Marszałkowski Województwa Lubelskiego: Lublin, Poland, 2014.

54. Zarząd Województwa Lubelskiego. Plan Zagospodarowania Przestrzennego Województwa Lubelskiego; Zarząd Województwa Lubelskiego: Lublin, Poland, 2015.

55. Urząd Marszałkowski Województwa Lubelskieg. Program Rozwoju Turystyki w Województwie Lubelskim do 2020 Roku z Perspektywa do 2030; Urząd Marszałkowski Województwa Lubelskiego: Lublin, Poland, 2016.

56. Tomaszów Lubelski: Lublin. Strategiczny Plan Terytorialno-Funkcjonalny w Ramach Inicjatywy "Aktywne Roztocze" do 2023 r; Tomaszów Lubelski: Lublin, Poland, 2016. 
57. Ustawa z dnia 27 marca 2003, r.o planowaniu i zagospodarowaniu przestrzennym. Dziennik Ustaw nr 80/2003 poz. 717 (tekst jedn. Dz. U. 2018; p. 1945). Available online: http://prawo.sejm.gov.pl/isap.nsf/ DocDetails.xsp?id=WDU20030800717 (accessed on 18 February 2020).

58. Ustawa z dnia 16 kwietnia 2004 r. o ochronie przyrody. Dziennik Ustaw nr 92/2004 poz. 880 (tekst jedn. Dz. U.2018; p. 1614). Available online: http://prawo.sejm.gov.pl/isap.nsf/DocDetails.xsp?id=WDU20040920880 (accessed on 18 February 2020).

59. Alexandrowicz, Z.; Miśkiewicz, K. Geopark-od idei do realizacji, ze szczególnym uwzględnieniem Polski. Chrońmy Przyr. Ojczysta 2016, 72, 243-253.

60. Mc Keever, P.J.M.; Zouros, N. Geoparks: Celebrating Earth Heritage. Sustaining Local Communities. Episodes 2005, 28, 274-278. [CrossRef] [PubMed]

61. Baran-Zgłobicka, B.; Harasimiuk, M. Znaczenie badań geograficznych w poprawie jakości planowania w jednostkach samorządu terytorialnego różnego szczebla. Barom. Reg. 2016, 14, 127-140.

62. Zouros, N.; Mc Keever, P.J.M. European Geoparks: Geoconservation and Sustainable Local Development. In Proceedings of the International Conference "Studying, Modeling and Sense Making of Planet Earth", Lesvos, Greece, 1-6 June 2008; University of the Aegean: Lesvos, Greece, 2008.

63. Zouros, N.; Valiakos, I. Geoparks management and assessment. Bull. Geol. Soc. Greece 2010, 43, $965-977$. [CrossRef]

64. Gravis, I.; Németh, K.; Twemlow, C.; Németh, B. The Case for Community-Led Geoheritage and Geoconservation Ventures in Māngere, South Auckland, and Central Otago, New Zealand. Geoheritage 2020, 12, 19. [CrossRef]

65. Muntoni, F.; Balvis, T.; Rizzo, R.; Loru, P. Territorial Planning of Geological Mining Historical and Environmental Park of Sardinia. Geoheritage 2020, 12, 22. [CrossRef]

(C) 2020 by the authors. Licensee MDPI, Basel, Switzerland. This article is an open access article distributed under the terms and conditions of the Creative Commons Attribution (CC BY) license (http://creativecommons.org/licenses/by/4.0/). 